\title{
Trends in Brazilian Congress of Soil Science publications: An analysis of the 1947-2017 period
}

\author{
JULIERME Z. BARBOSA, GIOVANA C. POGGERE \& FATIMA M.S. MOREIRA
}

\begin{abstract}
The Brazilian Congress of Soil Science (Congresso Brasileiro de Ciência do Solo - CBCS) is the oldest soil science event in South America. The CBCS had 29,643 participants and 23,621 publications in 30 thematic areas between 1947 and 2017. There were only five editions of the CBCS (1947-1979) in which Soil Fertility did not produce the highest number of papers. Standardization of Soil Study Methods and Representation/ Soil Teaching was the most prolific in one year, and Soil Genesis, Morphology, and Cartography produced the most papers in the other four years. Subsequently, the area renamed as Soil Fertility and Plant Nutrition had the highest number of papers. By grouping papers into the scientific divisions of the Brazilian Society of Soil Science (Sociedade Brasileira de Ciência do Solo - SBCS), we verify that the division of Soil Use and Management had the most papers in most congresses. In 2017, the number of papers and the number of male researchers in the Brazilian National Council for Scientific and Technological Development were associated for each thematic area. The trends in CBCS publications were influenced by the natural and historic-economic characteristics of the country, in addition to changes that occurred in SBCS, universities, research institutes, and legislation.
\end{abstract}

Key words: Bibliometry, History, Pedology, Scientific research, Soil use and management.

\section{INTRODUCTION}

The first scientific studies of soils in Brazil were carried out from the nineteenth century onwards, in research institutes and agricultural schools. At the beginning of the following century, the development of soil science took place, due to the foundation of new research institutions and departments specializing in soils in Brazilian universities (Camargo et al. 2010). This occurred due to the great expansion of soil science worldwide, culminating in the birth of the International Society of Soil Science (currently known as the International Union of Soil Sciences - IUSS) in 1924 (van Baren et al. 2000). Later, the Brazilian Society of Soil Science
(Sociedade Brasileira de Ciência do Solo SBCS) was founded with 31 members (October 6-20, 1947, Rio de Janeiro). It aimed to improve communication and scientific propagation (Oliveira et al. 2015). The SBCS was the first national soil science society founded in Latin America, coinciding with the foundation of the Spanish Society of Soil Science (Sociedad Española de la Ciencia del Suelo) (October 10, 1947). The Latin American Soil Science Society (Sociedad Latinoamericana de la Ciencia del Suelo - SLCS) was created only a few years later (in 1954) (SLCS 2018). Since 1960, soil science has had an important boost in Brazil, due to the establishment of departments and postgraduate programs in soil science at several 
universities and other institutions (Camargo et al. 2010). Since its inception, the SBCS and its members have participated in the development of soil science at national and international levels, particularly through publications, multiinstitutional activities, and in the structuring of other scientific societies, such as SLCS and IUSS (van Baren et al. 2000, Oliveira et al. 2015, Barbosa \& Poggere 2016, SLCS 2018). These efforts culminated in the organization of the 21st World Congress of Soil Science (August 1217, 2018, Rio de Janeiro) (SBCS 2018).

The first Brazilian Meeting of Soil Science had 72 participants and 28 papers were published (Oliveira et al. 2015). From 1955 onwards, the event replaced the term "Meeting" with "Congress" and became known as the Brazilian Congress of Soil Science (Congresso Brasileiro de Ciência do Solo - CBCS) (Oliveira et al. 2015). Thus, in the present study, we refer to the event solely as CBCS. In 2017, consolidated as one of the world's largest national soil science events, the CBCS together with the SBCS, celebrated its 70th anniversary, with 1,240 participants and 1,652 papers published (SBCS 2017a). The importance of the event was not constricted by national boundaries; since the first events, the CBCS has attracted the spontaneous interest of participants from other countries (mainly from South America), and foreigners have been invited to participate in lectures (Oliveira et al. 2015). In addition, there are two further notable facts regarding the event: (1) since the first congress, there has never been an interruption in the frequency of the event (every two years); (2) in 1965, the CBCS was held concomitantly with the Latin American Congress of Soil Science (Oliveira et al. 2015, SBCS 2017a).

The organization of soil science into thematic areas or sub disciplines is commonly observed around the world (Barbosa \& Poggere 2016), and such divisions are common in other sciences. CBCS publications are also organized into thematic areas. Initially there were only seven, but currently there are 14 thematic areas. These thematic areas are the same as those that comprise the subdivisions of the SBCS, with themes grouped by similarity into four scientific divisions: Soil in Space and Time; Soil Processes and Properties; Soil Use and Management; Soils, Environment and Society (Oliveira et al. 2015). The organization of soil science into thematic areas was also adopted to separate Brazilian National Council for Scientific and Technological Development (Conselho Nacional de Desenvolvimento Científico e Tecnológico CNPq) research productivity fellows, although with fewer thematic areas (CNPq 2018). The research productivity fellow is a special funding for researchers who stand out among their peers and assesses their scientific contribution according to normative criteria established by CNPq. Thus, it may be possible to relate CBCS publications to the SBCS divisions and CNPq research productivity fellows, to further our understanding of Brazilian soil science.

There are some studies in the literature that have evaluated soil science publications in Brazil, considering general aspects (Garrido \& Garrido 2007, Prado 2008, Trajano et al. 2013) or thematic areas (Barreto et al. 2009, Bressiani et al. 2015, Mores et al. 2016, Tavares et al. 2016). However, there are few studies of this nature that have looked at CBCS publications, which have the potential to reveal important information about the development of soil science in Brazil, given their scientific and temporal coverage. Therefore, the objectives of the present study were: (1) to carry out a systematic evaluation of CBCS publications between 1947 and 2017, covering the number of publications (total and per thematic area) and their characteristics; (2) to assess the contribution of the current SBCS divisions to the CBCS publications; (3) to evaluate 
the relationship between CBCS publications and the number of CNPq research productivity fellows.

\section{MATERIALS AND METHODS}

For information on all editions of the CBCS (Table I), multiple sources of data were consulted. The numbers of papers and participants were obtained from secondary sources; a digital version of the SBCS historical collection (Oliveira et al. 2015), and the SBCS bulletins (SBCS 2015a, SBCS 2017a). On the other hand, the number of papers per thematic area were obtained from primary sources; CBCS annals or programs (SBCS 1950, SBCS 1951a, SBCS 1951b, SBCS 1953, SBCS 1956, SBCS 1959, SBCS 1962, SBCS 1971a, SBCS 1971b, SBCS 1971C, SBCS 1971d, SBCS 1971e, SBCS 1971f, SBCS 1973, SBCS 1974, SBCS 1976, SBCS 1977, SBCS 1979, SBCS 1981, SBCS 1983, SBCS 1985, SBCS 1988, SBCS 1989, SBCS 1991, SBCS 1993, SBCS 1995 , SBCS 1997, SBCS 1999, SBCS 2001, SBCS 2003, SBCS 2005, SBCS 2007, SBCS 2009, SBCS 2011, SBCS 2013, SBCS 2015b, SBCS 2017b). The number of papers per thematic area in each edition of the CBCS was counted directly from primary sources and organized in a digital spreadsheet. During the collection of information from primary sources, the language and length of the publications were also noted.

Data were relativized for the analysis of CBCS papers because there was a high variation in the numbers of papers and thematic areas. Thus, the contribution (in percentage) of papers per thematic area was calculated in relation to the total number of papers in each CBCS edition.

Additionally, the contribution (in percentage) of each division that currently compose the scientific structure of the SBCS to the total number of papers in each edition of the CBCS was calculated. The divisions and their respective specialized commissions are: (1) Soil in Space and Time - Soil Genesis and Morphology, Soil Survey and Classification, Pedometrics; (2) Soil Processes and Properties - Soil Biology, Soil Physics, Soil Mineralogy, Soil Chemistry; (3) Soil Use and Management - Soil Fertility and Plant Nutrition, Correctives and Fertilizers, Soil and Water Management and Conservation, Pollution, Remediation and Recovery of Degraded Areas, Land Use Planning; and (4) Soils, Environment, and Society - Education on Soils and Public Perception of Soils, Soils and Food Security, History, Epistemology, and Sociology of Soil Science. For editions of CBCS that did not present thematic areas with the same nomenclature currently used, the papers were included in the corresponding area, which made it possible to calculate contribution by division. In addition, the number of CNPq research productivity fellows (total, female, and male) in thematic areas and the number of papers in corresponding areas of CBCS (2017 edition) were subjected to Pearson correlation analysis.

\section{RESULTS AND DISCUSSION}

\section{Participants and papers}

In the 36 editions published between 1947 and 2017, the CBCS had 29,643 participants and published 23,621 papers. In general, participants and papers began to increase in numbers (over 500 papers) consistently from the late 1970s (Figure 1). This increase is probably related to a number of changes that took place at the beginning of that decade, such as the establishment of the Brazilian Agricultural Research Corporation (Empresa Brasileira de Pesquisa Agropecuária - Embrapa), in addition to the establishment or expansion of other research and educational institutions (Camargo et al. 2010). Increases in food production in Brazil might also have influenced this trend, since more revenue was 
Table I. General information regarding the Brazilian Congress of Soil Science.

\begin{tabular}{|c|c|c|c|c|c|c|c|}
\hline$M / C^{1}$ & Year & Day/Month & City/FU ${ }^{2}$ & $M / C$ & Year & Day/Month & City/FU \\
\hline M & 1947 & 06 to $20 / \mathrm{OCT}$ & Rio de Janeiro/RJ & C & 1983 & 17 to $22 / J U L$ & Curitiba/PR \\
\hline M & 1949 & 16 to $23 / J U L$ & Campinas/SP & C & 1985 & 14 to $21 / J U L$ & Belém/PA \\
\hline M & 1951 & 17 to $29 / J U L$ & Recife/PE & C & 1987 & 19 to $25 / J U L$ & Campinas/SP \\
\hline M & 1953 & 06 to $15 / J U L$ & Belo Horizonte/MG & C & 1989 & 23 to $31 / J U L$ & Recife/PE \\
\hline C & 1955 & 04 to $15 / J U L$ & Pelotas/RS & C & 1991 & 21 to $27 / J U L$ & Porto Alegre/RS \\
\hline C & 1957 & 15 to $26 / J U L$ & Ilhéus/BA & C & 1993 & 25 to $31 / J U L$ & Goiânia/GO \\
\hline C & 1959 & 20 to $30 / J U L$ & Piracicaba/SP & C & 1995 & 23 to $29 / J U L$ & Viçosa/MG \\
\hline C & 1961 & 15 to $30 / J U L$ & Belém/PA & C & 1997 & 20 to $26 / J U L$ & $\begin{array}{l}\text { Rio de Janeiro/ } \\
\text { RJ }\end{array}$ \\
\hline C & 1963 & 15 to $20 / J U L$ & Fortaleza/CE & C & 1999 & 11 to $16 / J U L$ & Brasília/DF \\
\hline C & 1965 & 19 to $30 / J U L$ & Piracicaba/SP & C & 2001 & 01 to $08 / J U L$ & Londrina/PR \\
\hline C & 1967 & 17 to $22 / J U L$ & Brasília/DF & C & 2003 & 13 to $20 / J U L$ & $\begin{array}{c}\text { Ribeirão Preto/ } \\
\text { SP }\end{array}$ \\
\hline C & 1969 & 21 to $26 / J U L$ & Curitiba/PR & C & 2005 & 17 to $22 / J U L$ & Recife/PE \\
\hline C & 1971 & 12 to $22 / J U L$ & Vitória/ES & C & 2007 & 05 to $10 / A \cup G$ & Gramado/RS \\
\hline C & 1973 & 16 to $23 / J U L$ & Santa Maria/RS & C & 2009 & 02 to $07 / A \cup G$ & Fortaleza/CE \\
\hline C & 1975 & 14 to $20 / J U L$ & Campinas/SP & C & 2011 & $31 / J U L$ to $05 / A \cup G$ & Uberlândia/MG \\
\hline C & 1977 & 11 to $16 / J U L$ & São Luis/MA & C & 2013 & $28 / J U L$ to $02 / A \cup G$ & $\begin{array}{c}\text { Florianópolis/ } \\
\text { SC }\end{array}$ \\
\hline C & 1979 & 08 to $13 / J U L$ & Manaus/AM & C & 2015 & 02 to $07 / A \cup G$ & Natal/RN \\
\hline C & 1981 & $31 / A U G$ to $05 /$ SEPT & Salvador/BA & C & 2017 & $30 / \mathrm{JUL}$ to $05 / \mathrm{AUG}$ & Belém/PA \\
\hline
\end{tabular}

${ }^{1}$ Meeting or Congress. ${ }^{2} \mathrm{FU}$, federative unit.

generated for the country, possibly resulting in more investment in teaching and scientific research. This relationship becomes very evident from the end of the 1990s, with a large increase in the number of CBCS participants and papers (Figure 1) concomitant with an increase in Brazilian crops (mainly soybean, corn and orange) and meat production (Pereira et al. 2012, IPEA 2018). Finally, the drop in CBCS numbers for 2017 is likely due to the event's location (Pará, in the Amazon region), which is far from the states with the largest number of universities and research institutes. However, other factors may have influenced this decrease and, if it is a trend, may be confirmed at upcoming events.
The official language of the CBCS has always been Portuguese. However, since the first event, papers with abstracts in English, German or French, and later in Spanish, were registered. Already at that time, English was the most common alternative language used in the abstracts. However, it is interesting to note that the papers with an abstract in German were generally from southern Brazil, specifically Rio Grande de Sul, probably due to the number of German immigrants who arrived in the region in previous decades (Monasterio 2017). Papers with an abstract in English reached their peak in 1975, in the 15th edition of the CBCS, when all 94 papers contained an abstract in English. 


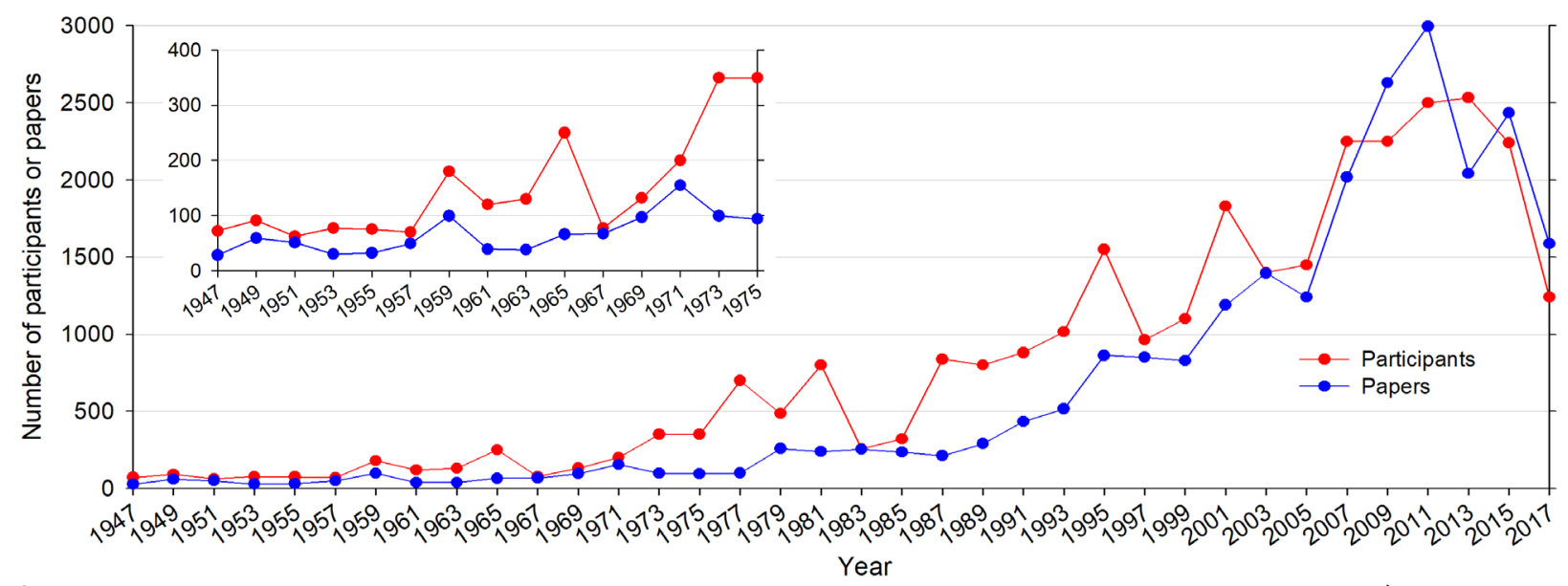

Figure 1. Numbers of participants and papers in each edition of the Brazilian Congress of Soil Science (Congresso Brasileiro de Ciência do Solo - CBCS) between 1947 and 2017. The subfigure highlights the numbers of participants and papers in the editions between 1947 and 1975. Sources: 1947-2013 (Oliveira et al. 2015); 2015-2017 (SBCS 2015a, SBCS 2017a).

Later, this type of publication fell into disuse and papers were published only in Portuguese, with the exception of a few papers published in English or Spanish.

In the first editions of the CBCS, the papers vary greatly in extent, containing between one and over 100 pages (including photographs and maps). From the 1970s onwards, the papers began to have a more uniform format, with generally fewer than four pages. This decrease occurred due to the increase in the number of papers published per event, which made it difficult to evaluate and organize CBCS annals. The Brazilian Journal of Soil Science (Revista Brasileira de Ciência do Solo) was created in 1977 (Oliveira et al. 2015) to publish more robust works. However, technological changes have modified the format of the CBCS annals, using CD-ROMs between 1997 and 2011 and the World Wide Web from 2013 onwards.

\section{Papers by thematic area}

The contribution of each thematic area in relation to the total number of papers in the CBCS edition had a different distribution pattern throughout the period from 1947 to 2017
(Figure 2). This was partly due to the variability in thematic areas, which numbered 30 in total. There were only five editions of the CBCS (19471979) in which the thematic area of Soil Fertility did not have the highest number of papers. Standardization of Soil Study Methods and Representation/Soil Teaching was the most prolific area in the first edition, and the area of Soil Genesis, Morphology, and Cartography produced the most papers in the four other editions (3rd, 9th, 12th and 15th). Subsequently (1981-2017), the area renamed as Soil Fertility and Plant Nutrition had the highest number of papers. The absolute prevalence of the Soil Fertility category since the end of the 1970s coincides with a period of expansion of Brazilian agriculture, which occurred due to advances in soil acidity and fertility correction programs that revitalized agriculture in the southern region and incorporated extensive areas of Cerrado in the productive process (Barbosa \& Poggere 2015, Lopes \& Guilherme 2016, Camargo et al. 2017). By analyzing 3,245 scientific articles published in Brazil between 1988 and 2007, Prado (2008) verified that the most important thematic area was Soil Fertility and Plant Nutrition in the 

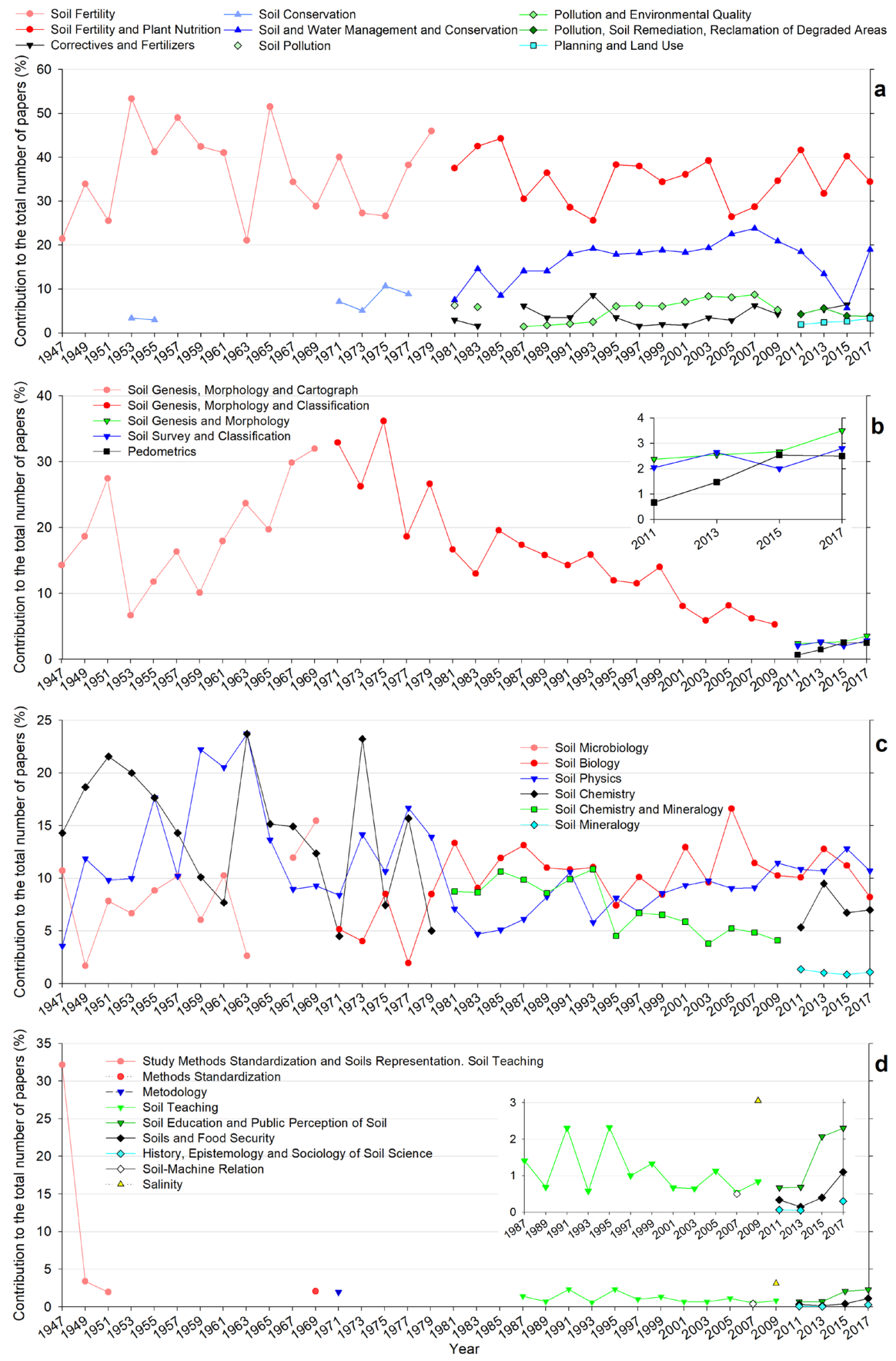

Figure 2. Contribution of thematic areas to the total number of papers published at the Brazilian Congress of Soil Science (Congresso Brasileiro de Ciência do Solo - CBCS) between 1947 and 2017. 
scientific journals Scientia Agricola, Pesquisa Agropecuária Brasileira, and Bragantia, but this was only the case in the Brazilian Journal of Soil Science until 1996. Now, Soil and Water Management and Conservation has become the most prolific category.

Soil Pollution became a thematic area 1981. It was later renamed as Soil Pollution and Environmental Quality, but since 2011, it has been called Pollution, Soil Remediation, and Recovery of Degraded Areas (Figure 2a). The thematic area of Soil Pollution was established in a decisive year for environmental issues in Brazil, with the enactment of Federal Law No. 6902, which provides for the creation of Environmental Protection Areas and Ecological Stations (Estações Ecológicas e Áreas de Proteção Ambiental), and the institution of the National Environmental Policy (Política Nacional do Meio Ambiente, Federal Law No. 6938). These changes can be interpreted as consequences of the rising concern about the impact of human activities on the environment, which had occurred more intensely since the 1970s (Pott \& Estrela 2017).

The period in which Soil Genesis, Morphology, and Classification reached its peak in the CBCS (1967-1975) (Figure 2b) coincides with part of the "golden phase" of Brazilian systematic soil surveys (1960-1986) (Ker et al. 2017). This phase was marked by: an increase in professionals working in the area, due to courses undertaken to train technicians to work on soil surveys or the specialization of Brazilians abroad; and the use of remote sensing tools (such as aerial photos and radar images). The work, carried out mainly by the Soil Commission of the National Agronomic Research Service of the Ministry of Agriculture (Serviço Nacional de Pesquisa Agronômica do Ministério da Agricultura) and the Radam-Brasil project, enabled the generation of Brazilian soil maps, and produced the main subsidies for the development of the Brazilian Soil Classification System (Sistema Brasileiro de Classificação de Solos - SiBCS) (Ker et al. 2017). However, the data indicate (Figure 2b) a declining trend for Soil Genesis, Morphology, and Classification papers in the CBCS within the period of the "golden phase" of soil surveys, which might be associated with the concentration of efforts around the generation and publication of surveys and soil maps at the end of this phase and the concurrent increase in the contribution of the other thematic areas. Later, there was a progressive decline in soil mapping and in the training of professionals in Pedology (Ker et al. 2017), which coincides with a decrease in the number of CBCS papers (Figure 2b). However, this was not verified by the number of scientific articles in the area of Soil Genesis and Morphology between 1988 and 2007 in the Brazilian Journal of Soil Science (Prado 2008). It is worth mentioning that in 2011, the Soil Genesis, Morphology, and Classification category was reorganized (into Soil Genesis and Morphology, and Soil Survey and Classification), and the area of Pedometrics also appeared. Pedometrics applies mathematical and statistical methods to study soil genesis, the distribution of soils, and their attributes (Webster 1994). A new phase of soil surveying in Brazil is commencing with the National Program of Brazilian Soils (Programa Nacional de Solos do Brasil - PronaSolos), which aims to promote continual multi-scale pedological surveys and interpretations (Polidoro et al. 2016). Thus, changes in the thematic areas associated with pedology may occur in the next editions of CBCS.

Soil Physics was the only thematic area present in all CBCS editions, with constant values close to $10 \%$, except for the period between 1959 and 1963, when it reached its peak of 20\% (Figure 2c). In general (until 1969), Soil Microbiology and later the thematic area 
of Soil Biology, had the lowest variation over the period evaluated, with values close to $10 \%$. Prado (2008) reported similar results for scientific articles published between 1988 and 2007 in the main Brazilian journals, with mean values of $10 \%$ for Soil Physics and Soil Biology. However, the results from the CBCS for the thematic area of Soil and Water Management and Conservation showed high variation (Figure 2c). The area of Soil Conservation appeared in the 4th edition and did not exceed 10\%; but from the 18th edition it began to be called Soil and Water Management and Conservation and reached values close to 20\% between 1991 and 2011. Prado (2008) verified average values of $10 \%$ for scientific articles published in the area of Soil and Water Management and Conservation between 1988 and 2007.

In 1947, the thematic area of Standardization of Soil Study Methods and Representation/Soil Teaching contributed $32 \%$ of the total of papers, but failed to exceed a contribution of $4 \%$ in the following two editions (Figure $2 \mathrm{~d}$ ). Subsequently, a similar thematic area returned to CBCS only in 1969 (Methodology) and 1971 (Standardization of Methods). Between 1987 and 2009, the thematic area of Soil Science Teaching was established, which from 2011 was called Education on Soils and Public Perception of Soil. This was also the period in which Soil and Food Security and History, Epistemology, and Sociology of Soil Science was included in CBCS (Figure 2d). The existence of thematic areas on methodologies and teaching in only five editions of the CBCS (between 1947 and 1985) (Figure 2d) may be due to the publication of methodologies within the specific areas and, in the case of teaching, a lack of concern regarding research. However, the permanent establishment of the thematic area of Soil Science Teaching in 1987 at the CBCS (Figure 2d) was preceded by modifications in the Brazilian teaching system, which are clearly associated with the valorization and expansion of soil science in the academic environment. In 1984, the minimum curriculum of agronomy courses in Brazilian universities was reformulated and soil science - which since 1975 had three focus areas (Soil Genesis, Morphology and Classification; Soil Fertility; Use and Conservation of Soils) - was then composed of the following areas: Elements of Geology and Mineralogy; Soil Genesis, Morphology, Survey and Classification; Soil Fertility, Correctives and Fertilizers; Soil and Water Management and Conservation; Soil Physics, Chemistry, and Biology (Beck 2010). The modification of the nomenclature of Soil Science Teaching to Education on Soils and Public Perception of Soil, and the creation of Soil and Food Security and History, Epistemology, and Sociology of Soil Science (Figure 2d) was influenced by the changes in the scientific structure of the SBCS, which was organized in a similar manner to the IUSS (Oliveira et al. 2015, Barbosa \& Poggere 2016).

The thematic areas Soil-Machine Relation and Salinity were only part of CBCS in 2007 and 2009, respectively (Figure $2 d$ ). The inclusion of these thematic areas probably occurred due to their regional importance. In 2007, CBCS was organized by the Federal University of Rio Grande do Sul (Universidade Federal do Rio Grande do Sul) (Oliveira et al. 2015), which had Soil-Machine Relation as a research area in their postgraduate course on soil science (Ceretta et al. 2008). In 2009, CBCS was organized by the Federal University of Ceará (Universidade Federal do Ceará), in the northeastern region of Brazil, where the country's largest concentration of saline soils occurs (Rocha Neto et al. 2017).

\section{Relationship of CBCS publications with the scientific divisions of SBCS and CNPq research productivity fellows}

Grouping CBCS papers according to the scientific divisions currently used in SBCS, revealed that 
between 1947 and 1975, there was variation in which division had the most papers. However, for most editions (especially since 1977) (Figure 3), the division of Soil Use and Management had the most papers, followed by Soil Processes and Properties; Soil in Space and Time; and Soils, Environment, and Society. This sequence of divisions is probably related to the number of researchers, since a survey of research areas of SBCS members revealed the same order of prevalence (Medeiros 2017). The highest contribution to the total number of CBCS papers by Soil Use and Management suggests that the agronomic aspect of soil science in Brazil was predominant, which is related to the historical importance of agriculture in Brazil's economy (Camargo et al. 2017, Paula et al. 2017). Additionally, the prevalence of Soil Use and Management papers in the CBCS probably also correlates with the fact that most soils in Brazil have low natural fertility and face issues relating to physical degradation susceptibility (Lopes \& Guilherme 2016, Rabel et al. 2018). Prado (2008) found similar results by assessing the prevalence of publications involving soil science among articles published between 1988 and 2007 in the main Brazilian journals. Regarding some other national soil science events, we found that in Argentina (AACS 2018) and India (ISSS 2017) most of the papers also occurred in the division of Soil Use and Management, with 67 and $64 \%$, respectively. However, it is possible to verify the greater contribution of publications in thematic areas associated with Soil Processes and Properties (40\%) compared to Soil Use and Management (28\%) for World Soil Science Congresses held between 1924 and 1998 (van Baren et al. 2000).

The CBCS papers in 2017 were not related to the total number of CNPq research productivity fellows in corresponding thematic areas (Table II). However, when the distinction by sex was made, it was possible to demonstrate that the papers were associated with the number of men, which was not the case when considering the number of women who received $\mathrm{CNPq}$ productivity fellows (Table $\mathrm{II}$ ). This may be due to male researchers working in all thematic areas but predominating in Soil Fertility and Fertilization (which has a high contribution to CBCS publications), whereas female researchers are most common in Soil Biochemistry and Microbiology (which has a low contribution to CBCS publications). In general, the higher number

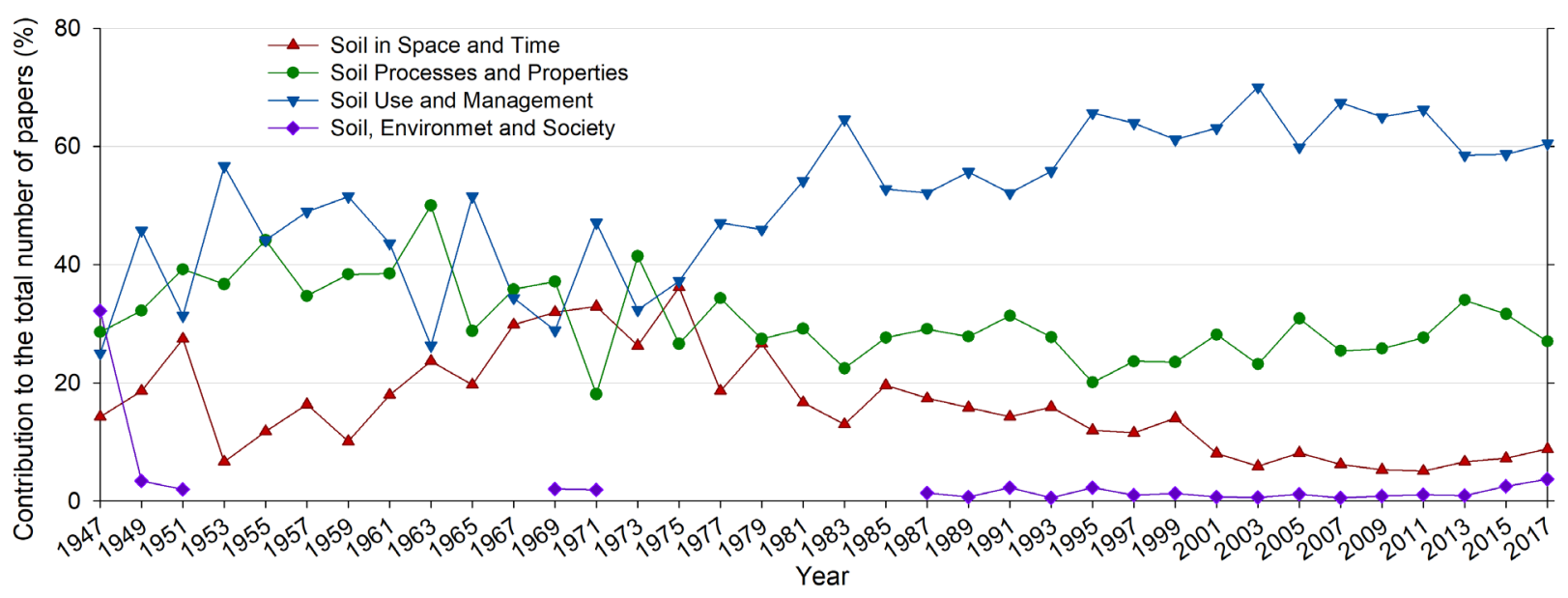

Figure 3. Percentage contribution of each division that currently compose the scientific structure of the Brazilian Society of Soil Science (Sociedade Brasileira de Ciência do Solo - SBCS) to the total number of papers of each Brazilian Congress of Soil Science (Congresso Brasileiro de Ciência do Solo - CBCS) between 1947 and 2017. 
of male researchers in all areas and the most similar numbers of male and female researchers in the biological area (Table II) corroborates the results of Ferrari et al. (2018), who analyzed the members of the Brazilian Academy of Sciences. In the SBCS, the number of male members is higher for all scientific divisions, however, the Soils, Environment and Society division had the least difference between male and female members (52\% versus 48\%) (Medeiros 2017). New studies about scientific publications are required to deepen our knowledge of sex differences in Brazilian soil science.

\section{CONCLUSION}

Thepresentstudy contributestotheunderstanding of Brazilian soil science development by revealing trends in 70 years of CBCS publications, in addition to exploring its association with the current divisions of SBCS and CNPq research productivity fellows. Soil Fertility (1947-1979), which was renamed as Soil Fertility and Plant Nutrition, had the highest number of papers in most editions of the CBCS. The predominance of papers in thematic areas associated with the division of Soil Use and Management (Soil Fertility and Plant Nutrition; Correctives and Fertilizers; Soil and Water Management and Conservation; Pollution, Remediation, and Recovery of Degraded Areas; Land Use Planning) was in line with the country's strong historical relationship with agriculture and soil-related issues. In addition, CBCS papers were influenced by striking changes that occurred in the SBCS, universities, research institutes, and legislation. At the same time, these changes were probably influenced, to some extent, by the CBCS papers themselves, given that CBCS publications were a powerful means to disseminate knowledge in soil science. Finally, the present study may be useful in fomenting fruitful discussions of several aspects, such as the structure of the CBCS, productivity of the thematic areas, and comparisons with events from other scientific societies.

Table II. Brazilian Congress of Soil Science (Congresso Brasileiro de Ciência do Solo - CBCS) papers and the number of Brazilian National Council for Scientific and Technological Development (Conselho Nacional de Desenvolvimento Científico e Tecnológico - CNPq) research productivity fellows by thematic area in 2017 and Pearson correlation coefficients.

\begin{tabular}{|c|c|c|c|c|}
\hline \multirow{2}{*}{ Thematic area ${ }^{1}$} & \multirow{2}{*}{ CBCS papers } & \multicolumn{3}{|c|}{ Researchers } \\
\hline & & \multirow{2}{*}{$\begin{array}{c}\text { Female } \\
4\end{array}$} & \multirow{2}{*}{$\begin{array}{c}\text { Male } \\
33\end{array}$} & \multirow{2}{*}{$\begin{array}{c}\text { Total } \\
37\end{array}$} \\
\hline Soil Fertility and Fertilization & 546 & & & \\
\hline Soil Physics & 170 & 1 & 17 & 18 \\
\hline Soil Biochemistry and Microbiology & 130 & 18 & 25 & 43 \\
\hline Soil Management and Conservation & 301 & 5 & 21 & 26 \\
\hline Soil Chemistry & 111 & 2 & 18 & 20 \\
\hline \multirow[t]{3}{*}{ Soil Genesis, Morphology and Classification } & 100 & 1 & 13 & 14 \\
\hline & & \multicolumn{3}{|c|}{ Pearson coefficient ${ }^{2}$} \\
\hline & & -0.08 & $0.82^{*}$ & 0.45 \\
\hline
\end{tabular}

${ }^{1}$ Thematic areas of CNPq; the corresponding areas were considered for CBCS. ${ }^{2}$ Pearson correlation coefficients were obtained for the relationship between the number of CNPq research productivity fellows and the number of papers published in the CBCS.* denotes significant $(p<0.05)$. 


\section{Acknowledgments}

We acknowledge Federal University of Lavras (Universidade Federal de Lavras - UFLA) and Federal University of Paraná (Universidade Federal do Paraná - UFPR) libraries for access to the printed versions of Brazilian Congress of Soil Science (Congresso Brasileiro de Ciência do Solo - CBCS) annals and programs, Nilton Curi (UFLA) for the CBCS program carried out in 1977, Jeferson Dieckow (UFPR) and Volnei Pauletti (UFPR) for some CBCS annals in CD-ROM version. Additionally, FMSM thank the Brazilian National Council for Scientific and Technological Development (Conselho Nacional de Desenvolvimento Científico e Tecnológico - CNPq) for scholarship of research productivity (grant number 304527/2016-5).

\section{REFERENCES}

AACS - ASOCIACIÓN ARGENTINA DE LA CIENCIA DEL SUELO. 2018. Actas XXVI Congreso Argentino de la Ciencia del Suelo. Buenos Aires: AACS, $1756 \mathrm{p}$.

BARBOSA JZ \& POGGERE GC. 2015. Crônicas de barranco: revelando outra face da Ciência do Solo, Lavras: Edição dos autores, $160 \mathrm{p}$.

BARBOSA JZ \& POGGERE GC. 2016. Development of national soil science societies in the BRICS group of countries: An overview. Bull Int Union Soil Sci 129: 64-72.

BARRETTO AGDOP, LINO IS \& SPAROVEK G. 2009. Bibliometria da pesquisa brasileira em erosão acelerada do solo: instituições, temas, espaço e cronologia. Rev Bras Ciênc Solo 33: 1845-1854.

BECK FL. 2010. Ensino superior de ciência do solo no Brasil - Trajetórias e transformações. In: Simpósio Brasileiro de Educação em Solos, 5., Curitiba. Curitiba: Universidade Federal do Paraná/ Sociedade Brasileira de Ciência do Solo, p. 5-9.

BRESSIANI DA, GASSMAN PW, FERNANDES JG, GARBOSSA LHP, SRINIVASAN R, BONUMÁ NB \& MENDIONDO EM. 2015. Review of soil and water assessment tool (SWAT) applications in Brazil: Challenges and prospects. Int J Agric Biol Eng 8: 9-35.

CAMARGO FA, ALVAREZ V, HUGO V \& BAVEYE PC. 2010. Brazilian soil science: from its inception to the future, and beyond. Rev Bras Ciênc Solo 34: 589-599.

CAMARGO FAO, SILVA LS, MERTEN GH, CARLOS FS, BAVEYE PC \& TRIPLETT EW. 2017. Brazilian agriculture in perspective: great expectations vs reality. Adv Agron 141: 53-114.
CERETTA CA, DOS ANJOS LHC \& SIQUEIRA JO. 2008. A pósgraduação em Ciência do Solo no Brasil: evolução e tendência. Rev Bras Pós-Graduação 5: 7-35.

CNPq - CONSELHO NACIONAL DE DESENVOLVIMENTO CIENTÍFICO E TECNOLÓGICO. 2018. Disponível em: http://lattes. cnpq.br/web/dgp/ciencias-agrarias. (Acessado $28 \mathrm{de}$ setembro de 2018).

FERRARI NC, MARTELL R, OKIDO DH, ROMANZINI G, MAGNAN V, BARBOSA MC \& BRITO C. 2018. Geographic and gender diversity in the Brazilian Academy of Sciences. An Acad Bras Cienc 90: 2543-2552.

GARRIDO RG \& GARRIDO FDSRG. 2007. Análise cientométrica da Revista Brasileira de Ciência do Solo: um retrato da ciência brasileira entre 2000 e 2005. Diálogos \& Ciência 5: 1-9.

IPEA - INSTITUTO DE PESQUISA ECONÔMICA APLICADA. 2018. IPEA Data. Disponivel em: http://www.ipeadata.gov.br/ (Acessado 28 de setembro de 2018).

ISSS - INDIAN SOCIETY OF SOIL SCIENCE. 2017. Abstracts: national seminar on developments in soil science 2016. New Delhi: ISSS, 220.

KER JC, MOTTA PEF \& OLIVEIRA VA. 2017. Levantamentos pedológicos e a evolução do conhecimento dos solos no Brasil. In: Curi N, Ker JC, Novais RF, Vidal-Torrado P and Schaefer CEGR (Eds), Pedologia: Solos dos biomas brasileiros, Viçosa: Sociedade Brasileira de Ciência do Solo, Viçosa, Brasil, p. 1-45.

LOPES AS \& GUILHERME LG. 2016. A Career Perspective on Soil Management in the Cerrado Region of Brazil. Adv Agron 137: 1-72.

MEDEIROS L. 2017. Boletim Informativo da Sociedade Brasileira de Ciência do Solo 43(1): 12-17.

MONASTERIO L. 2017. Surnames and ancestry in Brazil. PLOS ONE 12: e0176890.

MORES GV, ABBADE EB, KAWANO BR, DA SILVA RF \& CUGNASCA CE. 2016. An overview of the main topics on no-tillage researches. Rev Agronegócio Meio Ambiente 9: 357-369.

OLIVEIRA LB, MEDEIROS LR \& FARIAS GS. 2015. Sociedade Brasileira de Ciência do Solo: um olhar sobre sua história, $3^{a}$ ed., Viçosa: Sociedade Brasileira de Ciência do Solo, $177 \mathrm{p}$.

PAULA ADM, LIMA DT, TORRES JLR, RODRIGUES GI \& LEMES EM. 2017. Crop-livestock integration under no-tillage: genuine Brazilian technology with economic and environmental sustainability: A review. Aus I Crop Sci 11: 1161-1167.

PEREIRA PAA, MARTHA GB, SANTANA CA \& ALVES E. 2012. The development of Brazilian agriculture: future 
technological challenges and opportunities. Agric Food $\operatorname{Sec} 1: 1-4$.

POLIDORO JC ET AL. 2016. Programa Nacional de Solos do Brasil (PronaSolos). Rio de Janeiro: Embrapa Solos, 54 p.

POTT CM \& ESTRELA CC. 2017. Histórico ambiental: desastres ambientais e o despertar de um novo pensamento. Estud Av 31: 271-283.

PRADO RM. 2008. Diagnóstico sobre o conhecimento em Ciência do Solo no Brasil: a produção científica de periódicos de 1988 a 2007. Rev Bras Pós-Graduação 5: 303-321.

RABEL DO, MOTTA ACV, BARBOSA JZ, MELO VF \& PRIOR SA. 2018. Depth distribution of exchangeable aluminum in acid soils: A study from subtropical Brazil. Acta Sci Agron 40: e39320.

ROCHA NETO OCD, TEIXEIRA ADS, LEÃO RADO, MOREIRA LCJ \& GALVÃO LS. 2017. Hyperspectral remote sensing for detecting soil salinization using ProSpecTIR-VS aerial imagery and sensor simulation. Remote Sens 9: 42.

SBCS - SOCIEDADE BRASILEIRA DE CIÊNCIA DO SOLO. 1950. Anais da I Reunião Brasileira de Ciência do Solo, Rio de Janeiro: Sociedade Brasileira de Ciência do Solo, 679 p.

SBCS - SOCIEDADE BRASILEIRA DE CIÊNCIA DO SOLO. 1951a. Anais da III Reunião Brasileira de Ciência do Solo, v. 1, Rio de Janeiro: Sociedade Brasileira de Ciência do Solo, $542 \mathrm{p}$.

SBCS - SOCIEDADE BRASILEIRA DE CIÊNCIA DO SOLO. 1951b. Anais da III Reunião Brasileira de Ciência do Solo, v. 2, Rio de Janeiro: Sociedade Brasileira de Ciência do Solo, $914 \mathrm{p}$.

SBCS - SOCIEDADE BRASILEIRA DE CIÊNCIA DO SOLO. 1953. Anais da II Reunião Brasileira de Ciência do Solo, Rio de Janeiro: Sociedade Brasileira de Ciência do Solo, 760 p.

SBCS - SOCIEDADE BRASILEIRA DE CIÊNCIA DO SOLO. 1956. Anais da IV Reunião Brasileira de Ciência do Solo, Belo Horizonte: Sociedade Brasileira de Ciência do Solo, 427 p.

SBCS - SOCIEDADE BRASILEIRA DE CIÊNCIA DO SOLO. 1959. Anais do V Congresso Brasileiro de Ciência do Solo, Pelotas: Sociedade Brasileira de Ciência do Solo, 324 p.

SBCS - SOCIEDADE BRASILEIRA DE CIÊNCIA DO SOLO. 1962. Anais do VI Congresso Brasileiro de Ciência do Solo, Salvador: Sociedade Brasileira de Ciência do Solo, 240 p.

SBCS - SOCIEDADE BRASILEIRA DE CIÊNCIA DO SOLO. 1971a. Anais do VII Congresso Brasileiro de Ciência do Solo, Rio de Janeiro: Sociedade Brasileira de Ciência do Solo, 91 p.
SBCS - SOCIEDADE BRASILEIRA DE CIÊNCIA DO SOLO. 1971b. Anais do VIII Congresso Brasileiro de Ciência do Solo, Rio de Janeiro: Sociedade Brasileira de Ciência do Solo, 57 p. SBCS - SOCIEDADE BRASILEIRA DE CIÊNCIA DO SOLO. 1971C. Anais do IX Congresso Brasileiro de Ciência do Solo, Rio de Janeiro: Sociedade Brasileira de Ciência do Solo, 43 p.

SBCS - SOCIEDADE BRASILEIRA DE CIÊNCIA DO SOLO. 1971d. Anais do X Congresso Brasileiro de Ciência do Solo, Rio de Janeiro: Sociedade Brasileira de Ciência do Solo, 64 p.

SBCS - SOCIEDADE BRASILEIRA DE CIÊNCIA DO SOLO. 1971e. Anais do XI Congresso Brasileiro de Ciência do Solo, Rio de Janeiro: Sociedade Brasileira de Ciência do Solo, 405 p.

SBCS - SOCIEDADE BRASILEIRA DE CIÊNCIA DO SOLO. $1971 \mathrm{f}$. Anais do XII Congresso Brasileiro de Ciência do Solo, Rio de Janeiro: Sociedade Brasileira de Ciência do Solo, 76 p.

SBCS - SOCIEDADE BRASILEIRA DE CIÊNCIA DO SOLO. 1973. Anais do XIII Congresso Brasileiro de Ciência do Solo, Rio de Janeiro: Sociedade Brasileira de Ciência do Solo, 201 p.

SBCS - SOCIEDADE BRASILEIRA DE CIÊNCIA DO SOLO. 1974. Anais do XIV Congresso Brasileiro de Ciência do Solo, Santa Maria: Sociedade Brasileira de Ciência do Solo, 718 p.

SBCS - SOCIEDADE BRASILEIRA DE CIÊNCIA DO SOLO. 1976. Anais do XV Congresso Brasileiro de Ciência do Solo, Campinas: Sociedade Brasileira de Ciência do Solo, 616 p.

SBCS - SOCIEDADE BRASILEIRA DE CIÊNCIA DO SOLO. 1977. Programa do XVI Congresso Brasileiro de Ciência do Solo, Campinas: Sociedade Brasileira de Ciência do Solo, 80 p.

SBCS - SOCIEDADE BRASILEIRA DE CIÊNCIA DO SOLO. 1979. Anais do XVII Congresso Brasileiro de Ciência do Solo, Campinas: Sociedade Brasileira de Ciência do Solo, 102 p.

SBCS - SOCIEDADE BRASILEIRA DE CIÊNCIA DO SOLO. 1981. Programa e resumos do XVIII Congresso Brasileiro de Ciência do Solo, Campinas: Sociedade Brasileira de Ciência do Solo, 114 p.

SBCS - SOCIEDADE BRASILEIRA DE CIÊNCIA DO SOLO. 1983. Programa e resumos do XIX Congresso Brasileiro de Ciência do Solo, Campinas: Sociedade Brasileira de Ciência do Solo, 126 p.

SBCS - SOCIEDADE BRASILEIRA DE CIÊNCIA DO SOLO. 1985. Anais do XX Congresso Brasileiro de Ciência do Solo, Campinas: Sociedade Brasileira de Ciência do Solo, 188 p.

SBCS - SOCIEDADE BRASILEIRA DE CIÊNCIA DO SOLO. 1988. Anais do XXI Congresso Brasileiro de Ciência do Solo, 
Campinas: Sociedade Brasileira de Ciência do Solo, 525 p.

SBCS - SOCIEDADE BRASILEIRA DE CIÊNCIA DO SOLO. 1989. Programa e resumos do XXII Congresso Brasileiro de Ciência do Solo, Recife: Sociedade Brasileira de Ciência do Solo, 290 p.

SBCS - SOCIEDADE BRASILEIRA DE CIÊNCIA DO SOLO. 1991. Anais do XXIII Congresso Brasileiro de Ciência do Solo, Porto Alegre: Sociedade Brasileira de Ciência do Solo, 321 p.

SBCS - SOCIEDADE BRASILEIRA DE CIÊNCIA DO SOLO. 1993. Programa do XXIV Congresso Brasileiro de Ciência do Solo, Goiânia: Sociedade Brasileira de Ciência do Solo, $72 \mathrm{p}$.

SBCS - SOCIEDADE BRASILEIRA DE CIÊNCIA DO SOLO. 1995. Programa do XXV Congresso Brasileiro de Ciência do Solo, Campinas: Sociedade Brasileira de Ciência do Solo, $85 \mathrm{p}$.

SBCS - SOCIEDADE BRASILEIRA DE CIÊNCIA DO SOLO. 1997. Anais do XXVI Congresso Brasileiro de Ciência do Solo [CD-ROM], Campinas: Sociedade Brasileira de Ciência do Solo.

SBCS - SOCIEDADE BRASILEIRA DE CIÊNCIA DO SOLO. 1999. Anais do XXVII Congresso Brasileiro de Ciência do Solo [CD-ROM], Viçosa: Sociedade Brasileira de Ciência do Solo.

SBCS - SOCIEDADE BRASILEIRA DE CIÊNCIA DO SOLO. 2001. Anais do XXVIII Congresso Brasileiro de Ciência do Solo, Londrina: Sociedade Brasileira de Ciência do Solo, 367 p.

SBCS - SOCIEDADE BRASILEIRA DE CIÊNCIA DO SOLO. 2003. Anais do XXIX Congresso Brasileiro de Ciência do Solo [CD-ROM], Viçosa: Sociedade Brasileira de Ciência do Solo.

SBCS - SOCIEDADE BRASILEIRA DE CIÊNCIA DO SOLO. 2005. Anais do XXX Congresso Brasileiro de Ciência do Solo [CD-ROM], Viçosa: Sociedade Brasileira de Ciência do Solo.

SBCS - SOCIEDADE BRASILEIRA DE CIÊNCIA DO SOLO. 2007. Anais do XXXI Congresso Brasileiro de Ciência do Solo [CD-ROM], Viçosa: Sociedade Brasileira de Ciência do Solo.

SBCS - SOCIEDADE BRASILEIRA DE CIÊNCIA DO SOLO. 2009. Anais do XXXII Congresso Brasileiro de Ciência do Solo [CD-ROM], Viçosa: Sociedade Brasileira de Ciência do Solo.

SBCS - SOCIEDADE BRASILEIRA DE CIÊNCIA DO SOLO. 2011. Anais do XXXIII Congresso Brasileiro de Ciência do Solo [CDROM], Viçosa: Sociedade Brasileira de Ciência do Solo.
SBCS - SOCIEDADE BRASILEIRA DE CIÊNCIA DO SOLO. 2013. Anais do XXXIV Congresso Brasileiro de Ciência do Solo. Disponivel em: http://eventosolos.org.br/cbcs2013/ anais/ (Acessado 28 de setembro de 2018).

SBCS - SOCIEDADE BRASILEIRA DE CIÊNCIA DO SOLO. 2015a. Boletim Informativo da Sociedade Brasileira de Ciência do Solo 40(2): 4-6.

SBCS - SOCIEDADE BRASILEIRA DE CIÊNCIA DO SOLO. 2015b. Anais do XXXV Congresso Brasileiro de Ciência do Solo. Disponivel em: http://eventosolos.org.br/cbcs2015/ anais/index.html (Acessado 28 de setembro de 2018).

SBCS - SOCIEDADE BRASILEIRA DE CIÊNCIA DO SOLO. 2017a. Boletim Informativo da Sociedade Brasileira de Ciência do Solo 43(2): 4-8.

SBCS - SOCIEDADE BRASILEIRA DE CIÊNCIA DO SOLO. 2017b. Anais do XXXVI Congresso Brasileiro de Ciência do Solo. Disponivel em: http://icongresso.pauta.itarget.com.br/ anais (Acessado 28 de setembro de 2018).

SBCS - SOCIEDADE BRASILEIRA DE CIÊNCIA DO SOLO. 2018. Notícias. Boletim Informativo da Sociedade Brasileira de Ciência do Solo 44(1): 6-9.

SLCS - SOCIEDAD LATINOAMERICANA DE LA CIENCIA DEL SUELO. 2018. Available at: http://slcs.org.mx/index.php/en/ (Accessed 06 November 2018).

TAVARES LDF, CARVALHO AMXD \& MACHADO LG. 2016. An evaluation of the use of statistical procedures in soil science. Rev Bras Ciênc Solo 40: e0150246.

TRAJANO MA, CERETTA CA, RAZUCK FB \& SCHETINGER MR. 2013. Pós-graduação em ciência do solo no Brasil: Avanços e perspectivas. Rev Edu Agríc Super 28: 21-29.

VAN BAREN H, HARTEMINK AE \& TINKER PB. 2000. 75 years the International Society of Soil Science. Geoderma 96: 1-18.

WEBSTER R. 1994. The development of pedometrics. Geoderma 62: 1-15.

\section{How to cite}

BARBOSA JZ, POGGERE GC \& MOREIRA FMS. 2020. Trends in Brazilian Congress of Soil Science publications: An analysis of the 19472017 period. An Acad Bras Cienc 92: e20180710. DOI 10.1590/00013765202020180710 .

Manuscript received on July 11, 2018; accepted

for publication on December 24, 2018

\section{JULIERME Z. BARBOSA ${ }^{1}$}

https://orcid.org/0000-0002-1784-4985 


\section{GIOVANA C. POGGERE}

https://orcid.org/0000-0003-2434-9875

\section{FATIMA M.S. MOREIRA ${ }^{3}$}

https://orcid.org/0000-0003-0159-5811

'Departamento de Agronomia, Instituto Federal do Sudeste de Minas Gerais, Rua Monsenhor José Augusto,

204, São José, 36205-018 Barbacena, MG, Brazil

${ }^{2}$ Departamento de Ciências Biológicas e Ambientais, Universidade Tecnológica Federal do Paraná/UTFPR, Avenida Brasil, 4232, Independência, 85884-000 Medianeira, PR, Brazil

${ }^{3}$ Departamento de Ciência do Solo, Campus Universitário, Universidade Federal de Lavras/ UFLA, 37200-000 Lavras, MG, Brazil

Correspondence to: Julierme Zimmer Barbosa

E-mail:barbosajz@yahoo.com.br

\section{Author contributions}

Julierme Zimmer Barbosa - Designed the study, collected and analysed data, made figures and wrote the manuscript. Giovana Clarice Poggere and Fatima Maria de Souza Moreira - collected data and wrote the manuscript.

\section{(cc) BY}

